\title{
Checkpoints modulation by the Human T-lymphotropic virus type 1 Tax protein
}

\author{
Alexandre Carpentier ${ }^{1,2^{*}}$, Pierre-Yves Barez ${ }^{1,2}$, Mathieu Boxus ${ }^{1,2}$, Luc Willems ${ }^{1,2}$ \\ From 16th International Conference on Human Retroviruses: HTLV and Related Viruses \\ Montreal, Canada. 26-30 June 2013
}

HTLV-1 is responsible for two main diseases, Adult T-cell Leukemia/Lymphoma and HTLV-1 Associated Myelopathy/ Tropical Spastic Paraparesis, for which there is currently no satisfactory treatment. Among the proteins encoded by HTLV-1, Tax appears to play an important role in the mechanisms leading to pathogenicity. We are interested in the mechanisms of cell transformation by Tax and more particularly in the interplay between the viral Tax oncoprotein and the DNA damage response (DDR). We demonstrated that transient expression of Tax results in DNA damage, cell cycle arrest and activation of the DDR. In fibroblasts, cell cycle arrest occurs at the G1 and G2 phases depending on the p53 background. Although Tax induces apoptosis and senescence in fibroblasts, HTLV-1 infected lymphocytes proliferate continuously and appear to be adapted to the checkpoint control. This mechanism allows infected lymphocytes to proliferate despite the presence of genomic lesions. With these observations, we propose a novel therapeutic approach based on the principle of synthetic lethality.

\section{Authors' details}

${ }^{1}$ Molecular and Cellular Epigenetics, Interdisciplinary Cluster for Applied Genoproteomics (GIGA), University of Liège (ULg), Liège, Belgium. ${ }^{2}$ Molecular Biology Lab, Gembloux Agro Bio-Tech (ULg), Gembloux, Belgium.

Published: 7 January 2014

doi:10.1186/1742-4690-11-S1-P90

Cite this article as: Carpentier et al:: Checkpoints modulation by the Human T-lymphotropic virus type 1 Tax protein. Retrovirology 2014 11(Suppl 1):P90.

\footnotetext{
* Correspondence: A.Carpentier@doct.ulg.ac.be

${ }^{1}$ Molecular and Cellular Epigenetics, Interdisciplinary Cluster for Applied Genoproteomics (GIGA), University of Liège (ULg), Liège, Belgium
} Full list of author information is available at the end of the article

Submit your next manuscript to BioMed Central and take full advantage of:

- Convenient online submission

- Thorough peer review

- No space constraints or color figure charges

- Immediate publication on acceptance

- Inclusion in PubMed, CAS, Scopus and Google Scholar

- Research which is freely available for redistribution
( Biomed Central
C Biomed Central

(c) 2014 Carpentier et al; licensee BioMed Central Ltd. This is an Open Access article distributed under the terms of the Creative Commons Attribution License (http://creativecommons.org/licenses/by/2.0), which permits unrestricted use, distribution, and reproduction in any medium, provided the original work is properly cited. The Creative Commons Public Domain Dedication waiver (http://creativecommons.org/publicdomain/zero/1.0/) applies to the data made available in this article, unless otherwise stated. 